\title{
Frequency of Positive Surgical Margin at Prostatectomy and Its Effect on Patient Outcome
}

\author{
Kenneth A. Iczkowski and M. Scott Lucia \\ Department of Pathology, School of Medicine, University of Colorado Denver, Aurora, CO 80045, USA \\ Correspondence should be addressed to Kenneth A. Iczkowski, kenneth.iczkowski@ucdenver.edu \\ and M. Scott Lucia, scott.lucia@ucdenver.edu
}

Received 9 March 2011; Accepted 27 March 2011

Academic Editor: R. Montironi

Copyright (C) 2011 K. A. Iczkowski and M. S. Lucia. This is an open access article distributed under the Creative Commons Attribution License, which permits unrestricted use, distribution, and reproduction in any medium, provided the original work is properly cited.

\begin{abstract}
A positive surgical margin at prostatectomy is defined as tumor cells touching the inked edge of the specimen. This finding is reported in $8.8 \%$ to $42 \%$ of cases (median about $20 \%$ ) in various studies. It is one of the main determinants of eventual biochemical (PSA) failure, generally associated with a doubled or tripled risk of failure. The effect of a positive margin on outcome can be modified by stage or grade and the length, number and location of positive margins, as well as by technical operative approach and duration of operator experience. This paper tabulates data from the past decade of studies on margin status.
\end{abstract}

\section{Introduction}

1.1. Definition of a Positive Surgical Margin (PSM) in Radical Prostatectomy Specimens. As with all surgical specimens resected for cancer, the margins of a prostatectomy specimen are inked, usually using one color dye for the right side and one for the left. It is the pathologist's task to assess the microscopic slides and determine the proximity of tumor glands or cells to the ink to decide whether there is a definite positive surgical margin (PSM) (Figure 1).

A fundamental question is whether a tumor focus that is close to, but not touching, the resection margin (Figure 2) holds the same implications as a PSM. This question was first answered by Epstein and Sauvageot in 1997, in a study of 101 cases [1]. They found that patients with biochemical progression were no more likely to have tumor close to the margin than those without progression. Emerson et al., confining their study to just 278 margin-negative wholemount prostate cases, validated that the closest distance between tumor and resection margin was not a significant predictor of PSA recurrence by univariate or multivariate analysis [2]. Thus, it was the consensus of the International Society of Urological Pathology in 2009 not to mention in written reports if tumor merely approaches but does not touch the margin [3]. This contrasts with the practice in other types of specimens such as breast lumpectomy specimens, in which the distance of tumor close to the margin is reported and does matter for outcome.

A PSM is a strong determinant of the probability of biochemical failure and is at least as important as grade, stage, and preoperative serum prostate-specific antigen (PSA). In unselected contemporary studies the PSM rate ranges from $8.8 \%$ [4] to $37 \%$ [5]. The interobserver reproducibility of designation of a PSM by urologic pathologists, using the definition of tumor on ink, has been shown to be good to excellent. The kappa value is 0.73 for definitive surgical margin status [6]. This supports the validity of many studies in concluding that, compared to negative surgical margin (NSM) status, a PSM correlates with a significant rise in biochemical failure rate. The purpose of this paper is to provide a compendium for urologists and their patients of all that is known about prostate margin status as an outcome predictor.

\section{Methods}

A review of papers pertaining to prostate margin status and its effect on outcome was undertaken using PubMed searches from 1997 to the present. 
TABLE 1: Comparison of PSM rates by technical approach.

\begin{tabular}{|c|c|c|c|c|c|c|c|c|c|c|}
\hline \multirow{2}{*}{$\begin{array}{l}\text { First author, } \\
\mathrm{yr}\end{array}$} & \multirow{2}{*}{ No. of pts } & \multirow{2}{*}{$\begin{array}{l}\text { Cohort } \\
\text { years }\end{array}$} & \multirow{2}{*}{$\begin{array}{l}\text { Median } \\
\text { f/u, yr }\end{array}$} & \multicolumn{2}{|c|}{ Open } & \multicolumn{2}{|c|}{ Laparoscopic } & \multicolumn{2}{|c|}{ Robotic } & \multirow{2}{*}{$\begin{array}{l}\text { Failure } \\
\text { rate if PSM }\end{array}$} \\
\hline & & & & PSM rate & $P$ value & PSM rate & $\mathrm{HR}, P$ val. & PSM rate & $\mathrm{HR}, P$ val. & \\
\hline $\begin{array}{l}\text { Williams } \\
2010 \text { [7] }\end{array}$ & 4240 & $\begin{array}{c}2004- \\
2006\end{array}$ & & $20.1 \%$ & & $17.4 \%$ & & $17.4 \%$ & & \\
\hline $\begin{array}{l}\text { Coelho } \\
2010[8]\end{array}$ & $\geq 250^{\dagger \dagger}$ & $\begin{array}{c}1994- \\
2009\end{array}$ & & $24.0 \%$ & & $21.3 \%$ & & $13.6 \%$ & & \\
\hline $\begin{array}{l}\text { Sciarra } \\
2010[9]\end{array}$ & 200 & $\begin{array}{c}2003- \\
2007\end{array}$ & & $\begin{array}{c}18 \% \\
\text { anterograde, } \\
14 \% \\
\text { retrograde }\end{array}$ & $P=.03$ & - & & - & & - \\
\hline $\begin{array}{l}\text { Williams } \\
2010[10]\end{array}$ & 950 & $\begin{array}{c}2005- \\
2008\end{array}$ & & $7.6 \%$ & & $13.5 \%$, & $\begin{array}{l}\text { HR } 1.9^{*}, \\
P=.007\end{array}$ & - & & - \\
\hline $\begin{array}{l}\text { Coelho } \\
2010[11]\end{array}$ & 876 & $\begin{array}{l}2008- \\
2009\end{array}$ & & - & & - & & $\begin{array}{l}\text { pT2, 6.8\%, } \\
\text { pT3, 34.0\% }\end{array}$ & $P<.0001$ & - \\
\hline $\begin{array}{l}\text { Guru } \\
2009 \text { [12] }\end{array}$ & 480 & $\begin{array}{c}2005- \\
2008\end{array}$ & & - & & - & & $\begin{array}{c}5 \% \text { apical, } \\
2 \% \text { versus } \\
8 \% * *\end{array}$ & & - \\
\hline $\begin{array}{l}\text { Bong } \\
2009 \text { [13] }\end{array}$ & 301 & $\begin{array}{c}1994- \\
2006\end{array}$ & 2.0 & $\begin{array}{c}24.7 \% \text { at } 1 \\
\text { institution } \\
\text { but } 4.2 \% \text { at } \\
\text { another }\end{array}$ & $P<.01^{* * *}$ & - & & - & & $\begin{array}{c}25.6 \% \text { at } 1 \\
\text { institution } \\
\text { but } 100 \% \\
\text { at other }\end{array}$ \\
\hline $\begin{array}{l}\text { Hakimi } \\
2009[14]\end{array}$ & 150 & $\begin{array}{c}2001- \\
2008\end{array}$ & & & & $13.7 \%$ & & $12 \%$ & & $\begin{array}{c}6.7 \% \\
\text { versus } \\
5.3 \% \\
P=.37\end{array}$ \\
\hline $\begin{array}{l}\text { Laurila } \\
2009 \text { [15] }\end{array}$ & 192 & 2006 & & $14 \%$ & & - & & $13 \%$ & $\begin{array}{c}P=.5, \text { no } \\
\text { diff in } \\
\text { apical } \\
\text { margin }\end{array}$ & - \\
\hline $\begin{array}{l}\text { Terakawa } \\
2008[16]\end{array}$ & 137 & $\begin{array}{c}2000- \\
2007\end{array}$ & & PSM & Not signif. & - & & $\begin{array}{c}\text { More } \\
\text { multiple } \\
\text { PSM, get \# }\end{array}$ & & - \\
\hline $\begin{array}{l}\text { Smith } \\
2007 \text { [17] }\end{array}$ & 400 & $\begin{array}{c}2002- \\
2006\end{array}$ & & $35 \%^{\dagger}$ & & - & & $15 \%$ & $P<.001$ & - \\
\hline $\begin{array}{l}\text { Silva } \\
2007 \text { [18] }\end{array}$ & 179 & $\begin{array}{c}1999- \\
2003\end{array}$ & & $41.6 \%$ & & - & & $24.44 \%$ & $P=.023$ & - \\
\hline $\begin{array}{l}\text { Touijer } \\
2007 \text { [19] }\end{array}$ & 1177 & $\begin{array}{c}2003- \\
2005\end{array}$ & & $\begin{array}{c}11.0 \% \\
\text { pT2 } 5.3 \% \\
\text { pT3 } 22.0 \%\end{array}$ & & $\begin{array}{c}11.3 \% ; \\
\text { pT2 } 8.2 \% \text {; } \\
\text { pT3 } 17.2 \%\end{array}$ & $\begin{array}{c}\text { HR } 1.2, \\
P=.5\end{array}$ & - & & - \\
\hline
\end{tabular}

${ }^{*}$ OR falls to 1.6 if nerve-sparing is eliminated as a variable $(P=.05)$.

$* *$ Lower rate achieved by cold incision of the dorsal venous complex before suture ligation.

*** For the same surgeon; but higher average pathologic stage at the first institution.

${ }^{\dagger}$ But open method was used for more high-risk cases and also cases with a higher preoperative PSA, $P=.002$.

${ }^{\dagger \dagger}$ Review of several papers.

\section{Results}

3.1. Can Prostate Biopsy Results Predict Margin Status? We undertook a study a few years ago to determine the extent to which prostate biopsy results could predict cancer at prostatectomy that is unifocal, unilateral, margin-negative, and of small volume [20]. These four factors are the main criteria for choosing minimally invasive therapies such as targeted focal ablation of the prostate, as alternatives to radical prostatectomy. Unilateral cancer at prostatectomy was predicted by unilateral cancer in the biopsy (OR, 4.30) and unifocal cancer in the biopsy (OR, 2.63). In that study, negative surgical margins were predicted by unilateral cancer in the biopsy (OR 2.53, positive predictive value $82 \%$ ). Therefore, biopsy findings can strongly predict prostatectomy margin status and other findings.

3.2. Comparison of PSM Rates by Technical Approach (Table 1). In the past decade, nonrobotic or robotic laparoscopic techniques have been increasingly used in place of conventional open radical prostatectomy. The laparoscopic approaches are often considered superior for continence and potency $[8,11,12,14,16]$. Most studies involving prostate 
TABLE 2: Comparison of PSM rates by duration of surgical experience.

\begin{tabular}{|c|c|c|c|c|c|}
\hline \multirow{2}{*}{ First author, yr } & \multirow{2}{*}{ Number of cases } & \multirow{2}{*}{ Cohort years } & \multicolumn{3}{|c|}{ PSM rate } \\
\hline & & & Open & Laparoscopic & Robotic \\
\hline Rodriguez 2010 [21] & 400 , by intervals of 100 & 2004-2006 & - & $\begin{array}{c}\text { For pT2: } \\
28.4 \%-31.9 \% \text { to } \\
11.6 \%-11.5 \% *\end{array}$ & - \\
\hline Yee 2009 [22] & 50 , then 250 & 2005-2008 & - & - & $\begin{array}{c}\text { Cases } 1-50: 36 \% \text {, } \\
\text { 51-250: } 17.6 \% \text {, } \\
\text { 251-450: } 7.5 \%\end{array}$ \\
\hline Liss 2008 [23] & 216 & 2003-2007 & - & - & $\begin{array}{c}14.8 \% \text {, decr. over } \\
\text { time } P=.03 \\
\text { nerve-sparing } \\
\text { increased risk } \\
P=.03\end{array}$ \\
\hline Eastham 2007 [24] & 2442 & $\begin{array}{l}1983-1990 \\
\text { and } \\
1991-2004\end{array}$ & $\begin{array}{c}18 \% \text { versus } 10 \% \\
P=.001\end{array}$ & - & - \\
\hline Touijer 2007 [19] & 1177 & 2003-2005 & $\begin{array}{c}\text { No decrease over } \\
\text { time }\end{array}$ & $\begin{array}{c}\text { Decreased over } \\
\text { time, } P=.0002\end{array}$ & - \\
\hline
\end{tabular}

* First 200 cases versus last 200 cases.

TABLE 3: The effect of margin status on PSA failure rate at 10 years.

\begin{tabular}{|c|c|c|c|c|c|c|c|}
\hline \multirow{2}{*}{ First author, yr } & \multirow{2}{*}{$n$} & \multirow{2}{*}{ Cohort years } & \multirow{2}{*}{$\begin{array}{l}\text { PSA fail } \\
\text { criterion, ng/mL }\end{array}$} & \multirow{2}{*}{$\%$ PSM, overall } & \multicolumn{3}{|c|}{$\%$ biochemical failure rate } \\
\hline & & & & & PSM & NSM & $P$ value, HR \\
\hline Williams 2011 [25] & $158^{\dagger \dagger}$ & 2005-2009 & - & 13 & No $f / u$ & & \\
\hline Ahyai 2010 [26] & 932 & 1992-2004 & $\geq 0.1$ & 12.9 & 21.7 & 6.9 & $P=.001$ \\
\hline Tsao 2009 [27] & $100^{*}$ & 2004-2007 & $\geq 0.2$ & 23 & - & & \\
\hline Sæther 2008 [28] & 219 & 1996-2004 & $\geq 0.2$ & 32.4 & 40 & 18 & $P=.017$ \\
\hline Pfitzenmaier 2008 [29] & 406 & 1990-2006 & $\geq 0.2$ & 17.2 & 64.3 & 20.5 & $P<.001$, HR 3.21 \\
\hline Swanson 2007 [30] & 719 & 1985-1995 & $\geq 0.3$ & 15.3 & 63 & 27 & $P<.0001$ \\
\hline Ahyai 2010 [26] & 936 & $1992-2003$ & $\geq 0.4$ & 37 & 19 & 7 & $P<.01$ \\
\hline Kausik 2002 [31] & $1202^{\dagger}$ & 1987-1995 & $>0.2$ & 42 & 35 & 24 & $P=.0001$ \\
\hline Menon 2010 [32] & 1384 & $2001-2005^{*}$ & $\geq 0.2$ & 25.1 & - & - & $\begin{array}{c}P<.0001, \mathrm{HR} \\
2.43(1.72-3.42) \\
\end{array}$ \\
\hline
\end{tabular}

* Robotic only.

${ }^{\dagger} \mathrm{pT} 3$ cases only.

${ }^{+}$pT2 cases only.

pathology after laparoscopic approaches have found a PSM rate comparable with that of an open approach $[7,8,14$, $15,19]$. PSM rates were as follow: open, $7.6 \%$ [10] to $41.6 \%$ [18]; laparoscopic without robot, $11.3 \%$ [19] to $21.3 \%$ [8]; robotic, $13 \%$ [15] to $24.44 \%$ [18].

PSM rate for robotic approaches was found to be significantly worse than that for open ones $(P=.007)$ in one study [10]; however, two other studies found open approaches superior to the robotic ones $[17,18]$. In the study that found the open approach better, the result was confounded by nerve sparing, so robotic prostatectomies showed a nonsignificant trend toward lower PSM for a non-nerve-sparing approach $(P=.09)[10]$. When the anterograde open approach was compared with the retrograde approach, significantly fewer PSMs were found by retrograde approach $(P=.03)$ [9].

In a comparison of robotic versus nonrobotic laparoscopic approaches, one study found the robotic method superior [8]. Another found that the outcome was highly stage dependent, with $7 \%$ of pT2 patients with biochemical failure as opposed to $34 \%$ of pT3 patients [11]. Failure could also depend on number of positive margins [16]. In a study evaluating the robotic approach, a lower PSM rate was achieved by cold incision of the dorsal venous complex before suture ligation [12].

3.3. Comparison of PSM Rates by Duration of Surgical Experience (Table 2). In the above comparison of surgical approaches, it must be noted that the new laparoscopic approaches have a demonstrable learning curve. That is, in three studies conducted in the middle of the 2000-2010 decade, the PSM rate improved after a few years of practice [21-23]. While a significant decrease in PSM rate occurred over time with a laparoscopic approach, PSM held steady for open procedures during the same time period [19]. Even 


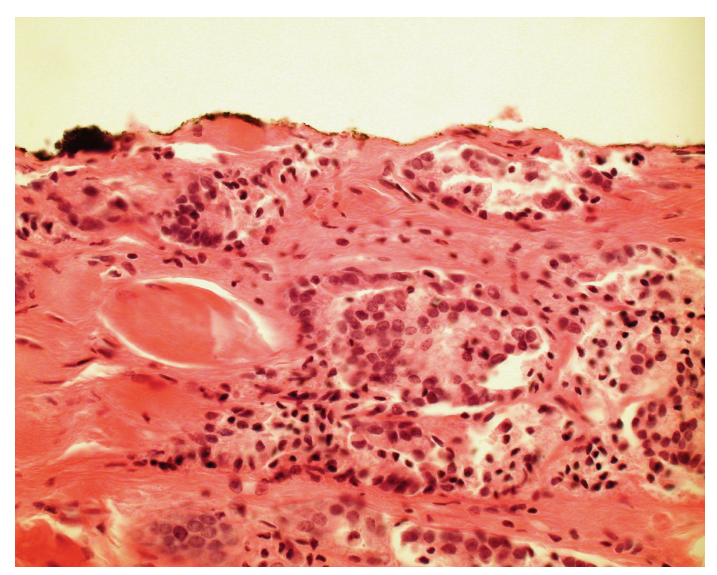

Figure 1: Prostatectomy specimen with a definite positive surgical margin (PSM). The inked resection margin transects tumor (400x).

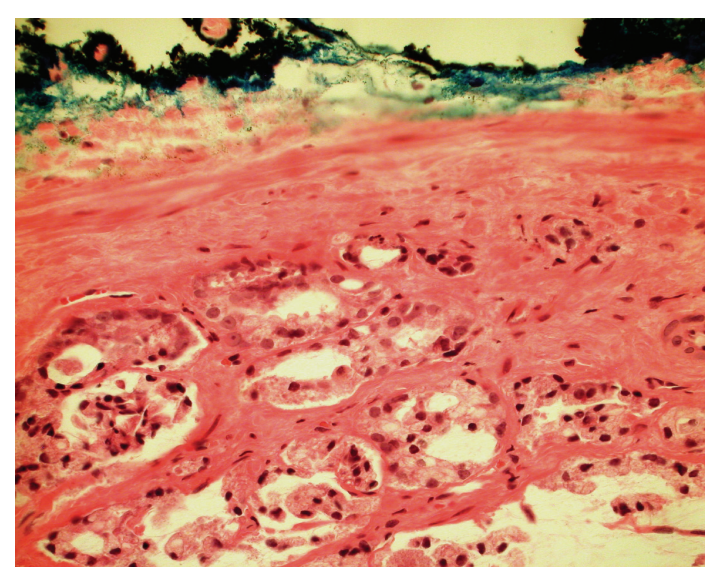

FIgURe 2: Prostatectomy specimen with negative surgical margin. Tumor approaches within less than 1 millimeter of the inked margin (400x).

with the open approach, during the 1990s and early 2000s, one study had noted that there was also a learning curve with respect to the PSM rate [24].

It is a bit disconcerting but it also must be admitted that individual surgeons may vary in their frequency of PSMs. In a study of 4,629 men operated on by open prostatectomy by one of 44 surgeons, for the 26 surgeons who each treated $>10$ patients, the rate of PSM ranged from $10 \%$ to $48 \%$ [33]. A 6 -fold difference was even reported for the same surgeon at different institutions [13].

3.4. Margin Status Effect on PSA Failure Rate at 10 Years (Table 3). PSM rates in studies not comparing approaches ranged from $13 \%$ [25] to $42 \%$ [31] with a median $23 \%$ [27]. In the presence of a PSM, the failure rate was either double $[28,30,32,34,40,42,43]$, triple $[5,26,29,38]$ or showed an increase of greater magnitude $[4,39]$ compared to NSM. Two studies did not specify this $[5,30]$. In studies reporting a Hazard Ratio (HR) comparing a PSM to NSM, the HR ranged from 1.3 [46] up to 3.66 [42].
3.5. Tumor Stage (Table 4) or Grade (Table 5) Can Modify the Effect of PSM on PSA Failure Rates, at 10 Years. Nine studies compared PSA failure rates as a function of pathologic stage pT3a and pT3b versus pT2 or of pT3 versus pT2. (The apparent stage sometimes cannot be assessed because of capsular incision [58].) Failure rates with a PSM in stage pT2 ranged from $10.6 \%$ [38] to 63\% [42], with an HR of 1.7 [4] to 3.81 [34] compared to having an NSM. For stage pT3a, failure rates were $38 \%$ [35] to 58\% [36], with HR ranging from $1.4[46]$ to 3.6 [4] compared to NSM. For stage pT3b, one study reports $71 \%$ failure, with HR of 1.4 compared to NSM [35]. Some studies chose to combine both pT3 substages and disclosed failure rates from 57\% [37] to 75\% [43] and HR of 4.1 [37] to 11.85 [38]. Thus, PSM exerts an effect that is synergistic with increasing stage, although the HR compared to NSM seems fairly constant across stages pT2, pT3a, and pT3b, at about 3 to 4 . A study examining the phenomenon of capsular incision, sometimes denoted pT2+, found a $29.3 \%$ failure rate versus $7.3 \%$ for no incision $(P<.0001)[46]$.

The HR for failure with a PSM seems to increase with increasing Gleason score [4, 35, 42, 44]. In one study [34], however, after controlling for Gleason score, a PSM versus NSM with Gleason $\leq 7$ was significantly predictive of failure, while PSM versus NSM with Gleason $\geq 8$ was not $(P=.115)$. Finally, Cao et al. noted that the Gleason score at the positive margin was predictive of biochemical recurrence [59]. Also, as the Gleason score of the main tumor rose, the concordance with the grade at the margin diminished: $99 \%$ for score 6 but $38 \%$ for score 9 . By multivariate analysis, Gleason score at the margin predicted biochemical failure $(P<.05)$ [59].

3.6. The Effect of PSM on Mortality Rate at 10 Years Is Also Modified by Stage and Grade (Table 6). Three studies addressed the prostate cancer-specific death rate in the presence of a PSM. Two studies, one based on the SEER cancer data registry [45], found a significantly higher death rate at 10 years in the presence of a PSM $[34,45]$, namely, $0.86 \%$ versus $0.33 \%(P<.001)$ and $2.6 \%$ versus $0.6 \%$ which was significant $(P=.006)$. In another study, from the Mayo Clinic registry, a PSM was not a significant predictor of death among 11,729 cases $(P=.15)$, but did predict death in the subset that was stage pT3 [34].

3.7. PSA Failure Rates after a PSM Are Influenced by Length and Number of PSM (Table 7) and by Location of PSM (Table 8). Many pathologists report the length of a PSM. Using categorical PSM length cut-offs between $3 \mathrm{~mm}$ and $10 \mathrm{~mm}$, length significantly affected outcome in many [36, 41, 47-49, 58] but not all [50-52] studies. Emerson et al. [53] found a PSM length $>3 \mathrm{~mm}$ to be a significant outcome predictor by univariate analysis but it fell short of significance by multivariate analysis $(P=.076)$ [53]. Moreover, the length of PSM by frozen section predicted residual tumor in additionally resected neurovascular bundles by multivariate analysis $(P<.001)[55]$.

The number of PSMs probably lacks predictive value. In most studies, number of PSM was not significant for 


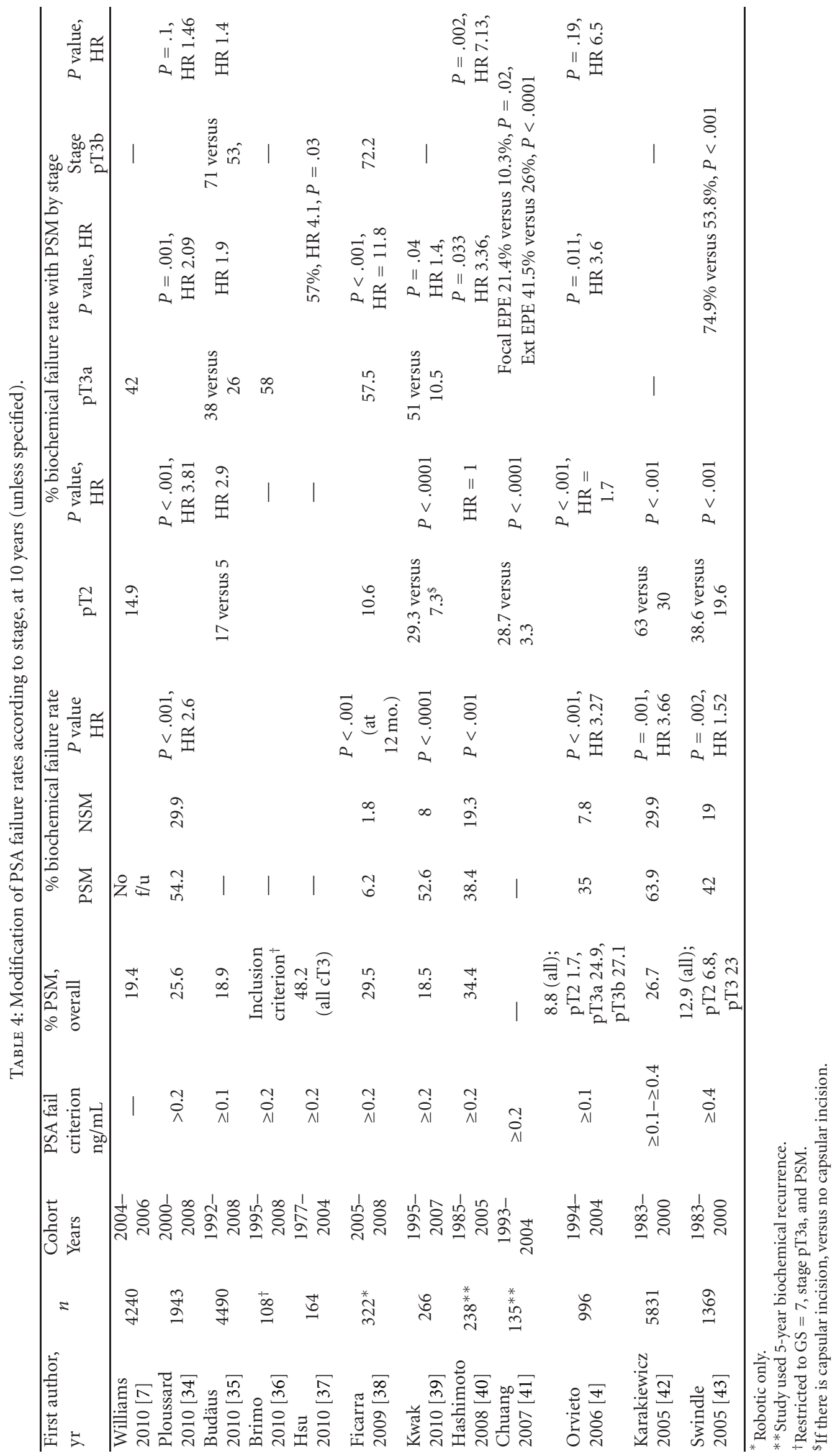


TABLE 5: Modification of PSA failure rates according to grade, at 10 years (unless specified).

\begin{tabular}{|c|c|c|c|c|c|c|c|c|c|}
\hline \multirow{2}{*}{$\begin{array}{l}\text { First author, } \\
\text { yr }\end{array}$} & \multirow{2}{*}{$n$} & \multirow{2}{*}{$\begin{array}{l}\text { Cohort } \\
\text { years }\end{array}$} & \multirow{2}{*}{$\begin{array}{l}\text { PSA Fail } \\
\text { criterion, ng/mL }\end{array}$} & \multirow{2}{*}{$\begin{array}{l}\text { \% PSM, } \\
\text { overall }\end{array}$} & \multicolumn{3}{|c|}{ \% biochemical failure rate } & \multicolumn{2}{|c|}{ Gleason score effect on failure if PSM } \\
\hline & & & & & PSM & NSM & $P$ value, $\mathrm{HR}$ & Comparisons & $P$ value, HR \\
\hline $\begin{array}{l}\text { Ploussard } \\
2010[34]\end{array}$ & 1943 & $\begin{array}{l}2000- \\
2008\end{array}$ & $>0.2$ & 25.6 & 54.2 & 29.9 & $\begin{array}{c}P<.001 \\
\text { HR } 2.6\end{array}$ & $\leq 7$ versus $\geq 8$ & $\begin{array}{l}P<.001 \\
P=.115\end{array}$ \\
\hline $\begin{array}{l}\text { Budäus } \\
2010 \text { [35] }\end{array}$ & 4490 & $\begin{array}{l}1992- \\
2008\end{array}$ & $\geq 0.1$ & 18.9 & - & - & & $\begin{array}{c}\text { compared to } \\
\mathrm{GS}=6: \text { for } 3+4 \\
\text { for } 4+3, \text { for } \geq 8\end{array}$ & $\begin{array}{c}\text { HR } 2.81 \\
\text { HR } 6.57 \text { HR 9.86, } \\
\text { all } P<.001\end{array}$ \\
\hline $\begin{array}{l}\text { Brimo } \\
2010[36]\end{array}$ & $108^{\dagger}$ & $\begin{array}{l}1995- \\
2008\end{array}$ & $\geq 0.2$ & $\begin{array}{l}\text { Inclusion } \\
\text { criterion }^{\dagger}\end{array}$ & - & - & & Score at margin & $P=.007$ \\
\hline $\begin{array}{l}\text { Alkhateeb } \\
2010[44]\end{array}$ & $11,729^{\ddagger}$ & $\begin{array}{l}1992- \\
2008\end{array}$ & $\geq 0.4$ & 31.1 & 56 & 77 & $\begin{array}{l}P<.0001 \\
\text { HR } 1.63\end{array}$ & $\begin{array}{l}\text { Low risk 5.1\% } \\
\text { versus } 0.4 \% \text {; } \\
\text { med. risk 17\% } \\
\text { versus } 65 \% \text {; } \\
\text { hi. risk } 43.9 \% \\
\text { versus } 21.5 \%\end{array}$ & - \\
\hline $\begin{array}{l}\text { Orvieto } \\
2006[4]\end{array}$ & 996 & $\begin{array}{c}1994- \\
2004\end{array}$ & $\geq 0.1$ & $\begin{array}{c}\text { All } 8.8 ; \\
\text { pT2 1.7, } \\
\text { pT3a 24.9, } \\
\text { pT3b 27.1 }\end{array}$ & 35 & 7.8 & $\begin{array}{l}P<.001 \\
\text { HR } 3.27\end{array}$ & 7 versus $\geq 8$ & $\begin{array}{l}P<.001, \text { HR } 7.2 \\
P<.001, \text { HR } 21\end{array}$ \\
\hline $\begin{array}{l}\text { Karakiewicz } \\
2005[42]\end{array}$ & 5831 & $\begin{array}{c}1983- \\
2000\end{array}$ & $\geq 0.1$ to $\geq 0.4$ & 26.7 & 63.9 & 29.9 & $\begin{array}{l}P=.001 \\
\text { HR } 3.66\end{array}$ & $\geq 7$ & $P \leq .008$, HR 2.81 \\
\hline
\end{tabular}

${ }^{\dagger}$ Restricted to GS = 7, stage pT3a, and PSM.

${ }^{\ddagger}$ Risk groups based on Gleason score and preoperative PSA: low $=$ PSA $<10$, Gleason $\leq 6$; medium = PSA 10-20 or Gleason 7; high = PSA $>20$ or Gleason $\geq 8$.

TABLE 6: Modification of prostate cancer mortality rates according to stage or grade, at 10 years.

\begin{tabular}{|c|c|c|c|c|c|c|c|c|c|c|c|}
\hline \multirow{2}{*}{$\begin{array}{l}\text { First author, } \\
\text { yr }\end{array}$} & \multirow{2}{*}{$n$} & \multirow{2}{*}{$\begin{array}{l}\text { PSA Fail } \\
\text { criterion, } \\
\mathrm{ng} / \mathrm{mL}\end{array}$} & \multirow{2}{*}{$\begin{array}{l}\text { PSM, } \\
\%\end{array}$} & \multirow{2}{*}{$\begin{array}{l}\text { Median } \\
\text { f/u, yr }\end{array}$} & \multicolumn{3}{|c|}{ PCa death rate if } & \multicolumn{2}{|c|}{ PSM rate or HR by stage } & \multicolumn{2}{|c|}{ PSM rate by grade } \\
\hline & & & & & PSM, \% & NSM, \% & $P$ value, $\mathrm{HR}$ & pT2 & pT3 a-b & Gleason $\geq 7$ & $P$ value \\
\hline $\begin{array}{l}\text { Wright } \\
2010 \text { [45] }\end{array}$ & 65,633 & - & 21.2 & 7 & 0.86 & 0.33 & $P<.001$ & $17.7 \%$ & $\begin{array}{c}43.8 \% \\
P<.001\end{array}$ & $\begin{array}{l}27.5 \% \\
\text { versus } \\
18.3 \%\end{array}$ & $P<.001$ \\
\hline $\begin{array}{l}\text { Boorjian } \\
2010[34]\end{array}$ & 11,729 & $\geq 0.4$ & 31.1 & 8.2 & 4 & 1 & $P=.15$ & HR 1.0 & $\begin{array}{c}\text { HR 2.1, } \\
P<.0001\end{array}$ & - & - \\
\hline $\begin{array}{l}\text { Ploussard } \\
2010[34]\end{array}$ & 1943 & $>0.2$ & 25.6 & 6.7 & 2.6 & 0.6 & $\begin{array}{c}P=.006 \\
3.7 \\
(1.5-9.5)\end{array}$ & 16.0 & $33.6-40.2$ & - & - \\
\hline
\end{tabular}

outcome [29, 31, 47, 49]. In two studies, multiple PSMs as opposed to a single PSM predicted failure (HR 1.4, $P=.002$ by multivariate analysis or $\mathrm{HR}=2.19)[54,58]$. In another study, number of PSMs carried only borderline significance when $\geq 3$ foci were positive compared to one $(P=.06)$ and not significant for 2 foci compared to one [50]. Emerson et al. found that PSM number predicted failure by univariate analysis $(P=.037)$ but lost most of its predictive value when adjusted for Gleason score $(P=.076)$ [53].

The most common location of a PSM was in the posterior or posterolateral prostate $[41,47,49]$, although one study found PSM equally common at the apex [24]. A positive apical soft tissue margin appears more consequential than a prostatic tissue margin [56]. Eastham et al. noted that the elevated risk of a posterior PSM means that "efforts to maintain adequate tissue covering including the routine excision of Denonvilliers' fascia and a component of the fat of the anterior rectal wall should be made in all patients..."
[24]. Broken down by various sites, a posterolateral PSM predicted failure in most studies [24, 48] but not all [49].

Comparing various sites of PSM, the effect of an apical PSM was not significantly different from PSM at posterolateral or other sites $[29,52,58]$, and another study concluded that the PSM location seemed not to predict failure [53]. However, in two studies, a positive posterolateral margin predicted failure while the apical margin did not [24, 57]. Possibly, residual apical tumor is less viable than residual tumor in the posterolateral region.

\section{Conclusion}

Prostate margin status is an important determinant of patient outcome after radical prostatectomy. In a 2010 College of American Pathologists survey, this feature was missing from $1 \%$ of pathology reports [60], thus the inclusion of this and other essential features is a quality assurance concern 


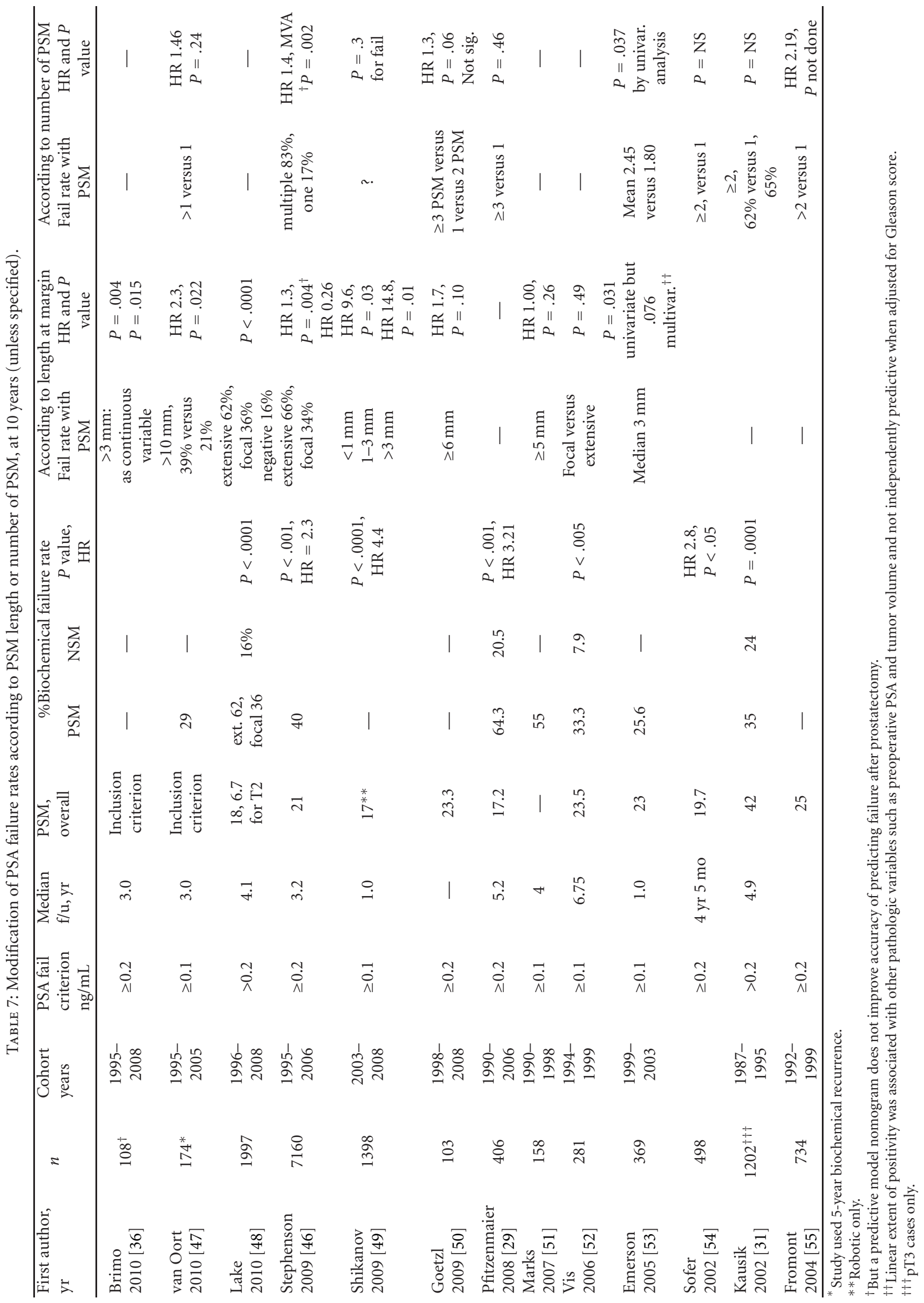




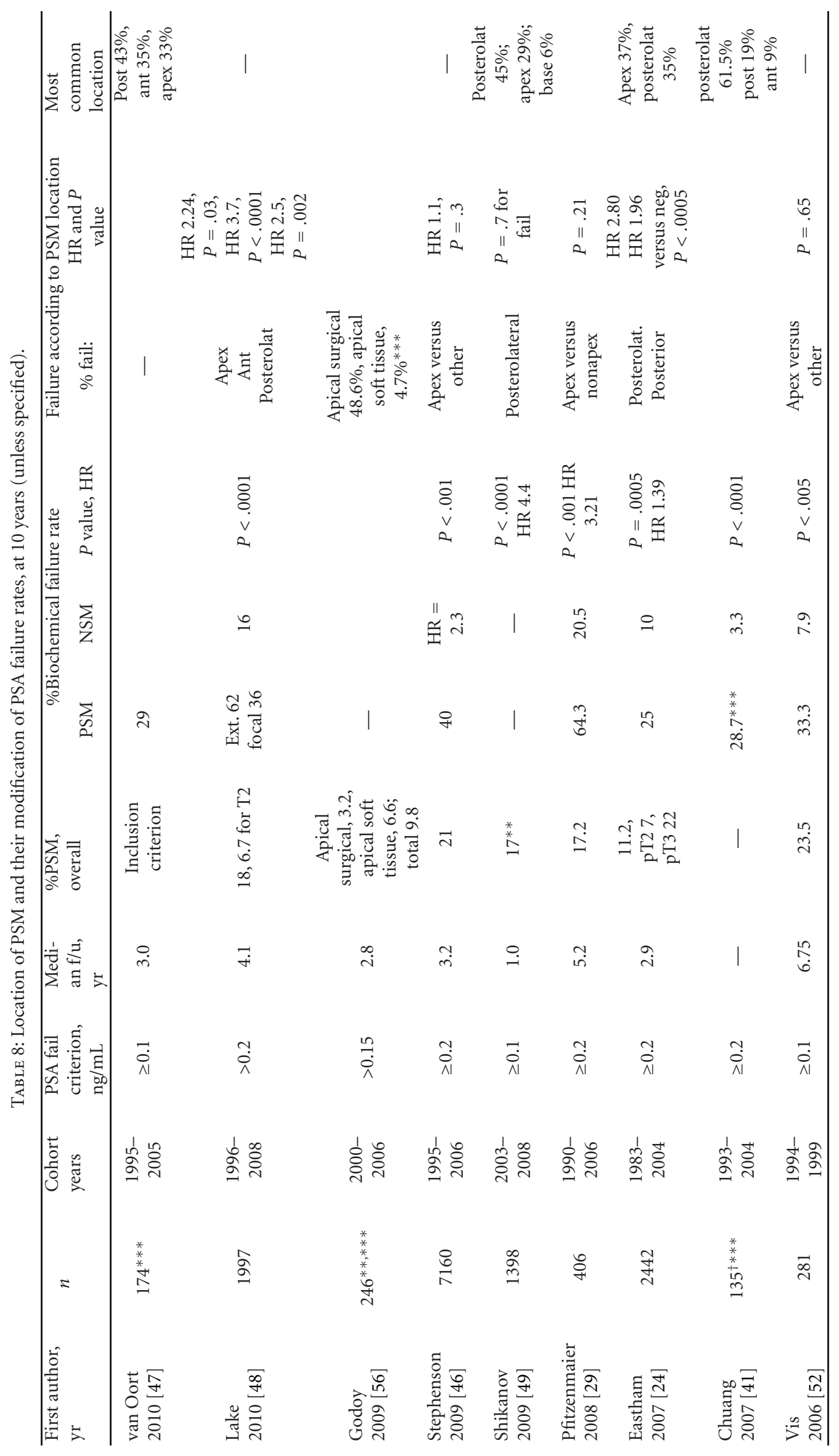




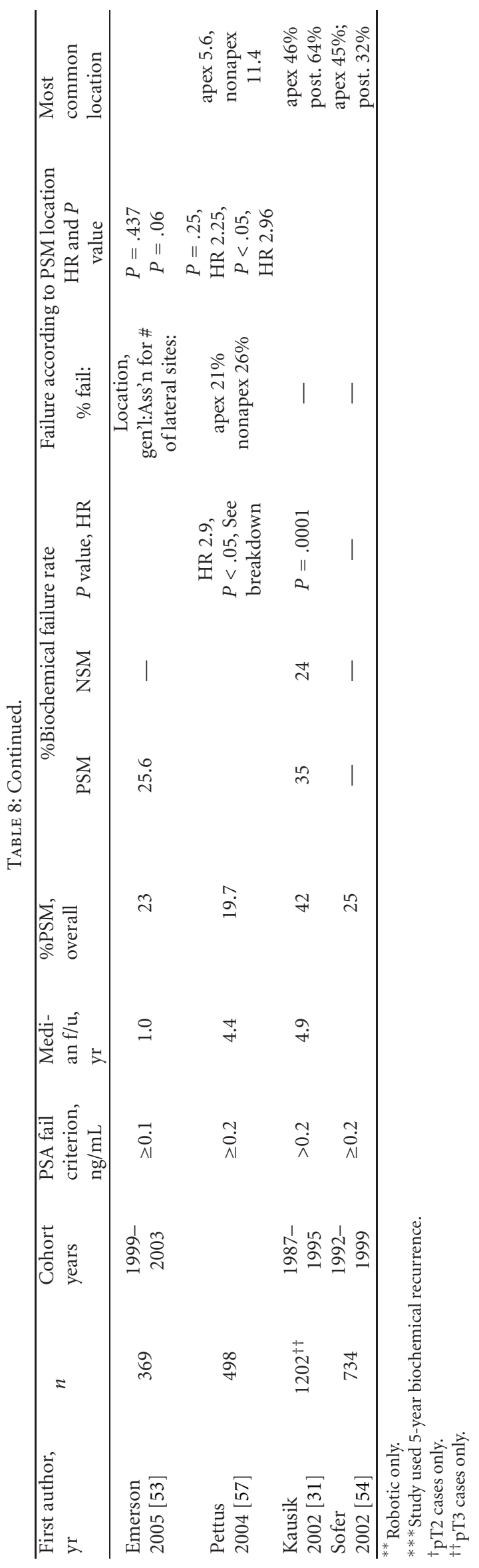


for pathologists. Most urologic pathologists endorse the reporting of the extensiveness of positive margins, expressed as length, number, or radial extent positive for tumor cells; all these measurements have some relevance toward outcome. The presence of a positive margin confers a 23 -fold increased hazard ratio for biochemical recurrencemodified by stage and tumor grade- and necessitates close clinical followup.

\section{References}

[1] J. I. Epstein and J. Sauvageot, "Do close but negative margins in radical prostatectomy specimens increase the risk of postoperative progression?" Journal of Urology, vol. 157, no. 1, pp. 241-243, 1997.

[2] R. E. Emerson, M. O. Koch, J. K. Daggy, and L. Cheng, "Closest distance between tumor and resection margin in radical prostatectomy specimens: lack of prognostic significance," American Journal of Surgical Pathology, vol. 29, no. 2, pp. 225229, 2005.

[3] P. H. Tan, L. Cheng, J. R. Srigley et al., "International society of urological pathology (ISUP) consensus conference on handling and staging of radical prostatectomy specimens. Working group 5: surgical margins," Modern Pathology, vol. 24, no. 1, pp. 48-57, 2011.

[4] M. A. Orvieto, N. F. Alsikafi, A. L. Shalhav et al., "Impact of surgical margin status on long-term cancer control after radical prostatectomy," BJU International, vol. 98, no. 6, pp. 1199-1203, 2006.

[5] M. A. Simon, S. Kim, and M. S. Soloway, "Prostate specific antigen recurrence rates are low after radical retropubic prostatectomy and positive margins," Journal of Urology, vol. 175, no. 1, pp. 140-144, 2006.

[6] A. J. Evans, P. C. Henry, T. H. Van Der Kwast et al., "Interobserver variability between expert urologic pathologists for extraprostatic extension and surgical margin status in radical prostatectomy specimens," American Journal of Surgical Pathology, vol. 32, no. 10, pp. 1503-1512, 2008.

[7] S. B. Williams, A. V. D’Amico, A. C. Weinberg, X. Gu, S. R. Lipsitz, and J. C. Hu, "Population-based determinants of radical prostatectomy surgical margin positivity," BJU International, vol. 107, pp. 1734-1740, 2011.

[8] R. F. Coelho, B. Rocco, M. B. Patel et al., "Retropubic, laparoscopic, and robot-assisted radical prostatectomy: a critical review of outcomes reported by high-volume centers," Journal of Endourology, vol. 24, no. 12, pp. 2003-2015, 2010.

[9] A. Sciarra, C. Cristini, M. von Heland, S. Salciccia, and V. Gentile, "Randomized trial comparing an anterograde versus a retrograde approach to open radical prostatectomy: results in terms of positive margin rate," Journal of the Canadian Urological Association, vol. 4, no. 3, pp. 192-198, 2010.

[10] S. B. Williams, M. H. Chen, A. V. D’Amico et al., "Radical retropubic prostatectomy and robotic-assisted laparoscopic prostatectomy: likelihood of positive surgical margin(s)," Urology, vol. 76, pp. 1097-1101, 2010.

[11] R. F. Coelho, S. Chauhan, M. A. Orvieto, K. J. Palmer, B. Rocco, and V. R. Patel, "Predictive factors for positive surgical margins and their locations after robot-assisted laparoscopic radical prostatectomy," European Urology, vol. 57, no. 6, pp. 10221029, 2010.
[12] K. A. Guru, A. E. Perlmutter, M. J. Sheldon et al., "Apical margins after robot-assisted radical prostatectomy: does technique matter?" Journal of Endourology, vol. 23, no. 1, pp. 123-127, 2009.

[13] G. W. Bong, C. W. M. Ritenour, A. O. Osunkoya, M. T. Smith, and T. E. Keane, "Evaluation of modern pathological criteria for positive margins in radical prostatectomy specimens and their use for predicting biochemical recurrence," $B J U$ International, vol. 103, no. 3, pp. 327-331, 2009.

[14] A. A. Hakimi, J. Blitstein, M. Feder, E. Shapiro, and R. Ghavamian, "Direct comparison of surgical and functional outcomes of robotic-assisted versus pure laparoscopic radical prostatectomy: single-surgeon experience," Urology, vol. 73, no. 1, pp. 119-123, 2009.

[15] T. A. J. Laurila, W. Huang, and D. F. Jarrard, "Robotic-assisted laparoscopic and radical retropubic prostatectomy generate similar positive margin rates in low and intermediate risk patients," Urologic Oncology, vol. 27, no. 5, pp. 529-533, 2009.

[16] T. Terakawa, H. Miyake, K. Tanaka, A. Takenaka, T. A. Inoue, and M. Fujisawa, "Surgical margin status of open versus laparoscopic radical prostatectomy specimens," International Journal of Urology, vol. 15, no. 8, pp. 704-708, 2008.

[17] J. A. Smith Jr., R. C. Chan, S. S. Chang et al., "A comparison of the incidence and location of positive surgical margins in robotic assisted laparoscopic radical prostatectomy and open retropubic radical prostatectomy," Journal of Urology, vol. 178, no. 6, pp. 2385-2390, 2007.

[18] E. Silva, U. Ferreira, G. D. Silva et al., "Surgical margins in radical prostatectomy: a comparison between retropubic and laparoscopic surgery," International Urology and Nephrology, vol. 39, no. 3, pp. 865-869, 2007.

[19] K. Touijer, K. Kuroiwa, J. A. Eastham et al., "Risk-adjusted analysis of positive surgical margins following laparoscopic and retropubic radical prostatectomy," European Urology, vol. 52, no. 4, pp. 1090-1096, 2007.

[20] K. A. Iczkowski, D. Hossain, K. C. Torkko et al., "Preoperative prediction of unifocal, unilateral, margin-negative, and small volume prostate cancer," Urology, vol. 71, no. 6, pp. 11661171, 2008.

[21] A. R. Rodriguez, K. Rachna, and J. M. Pow-Sang, "Laparoscopic extraperitoneal radical prostatectomy: impact of the learning curve on perioperative outcomes and margin status," Journal of the Society of Laparoendoscopic Surgeons, vol. 14, no. 1, pp. 6-13, 2010.

[22] D. S. Yee, N. Narula, M. B. Amin, D. W. Skarecky, and T. E. Ahlering, "Robot-assisted radical prostatectomy: current evaluation of surgical margins in clinically low-, intermediate, and high-risk prostate cancer," Journal of Endourology, vol. 23, no. 9, pp. 1461-1465, 2009.

[23] M. Liss, K. Osann, and D. Ornstein, "Positive surgical margins during robotic radical prostatectomy: a contemporary analysis of risk factors," BJU International, vol. 102, no. 5, pp. 603-607, 2008.

[24] J. A. Eastham, K. Kuroiwa, M. Ohori et al., "Prognostic significance of location of positive margins in radical prostatectomy specimens," Urology, vol. 70, no. 5, pp. 965-969, 2007.

[25] AK Williams, V Chalasani, CH Martínez et al., "Cumulative summation graphs are a useful tool for monitoring positive surgical margin rates in robot-assisted radical prostatectomy," BJU International, vol. 107, no. 10, pp. 1648-1652, 2011.

[26] S. A. Ahyai, M. Zacharias, H. Isbarn et al., "Prognostic significance of a positive surgical margin in pathologically 
organ-confined prostate cancer," BJU International, vol. 106, no. 4, pp. 478-483, 2010.

[27] A. K. Tsao, M. D. Smaldone, T. D. Averch, and S. V. Jackman, "Robot-assisted laparoscopic prostatectomy: the first 100 patients-improving patient safety and outcomes," Journal of Endourology, vol. 23, no. 3, pp. 481-484, 2009.

[28] T. Sæther, L. T. Sørlien, T. Viset, S. Lydersen, and A. Angelsen, "Are positive surgical margins in radical prostatectomy specimens an independent prognostic marker?" Scandinavian Journal of Urology and Nephrology, vol. 42, no. 6, pp. 514-521, 2008.

[29] J. Pfitzenmaier, S. Pahernik, T. Tremmel, A. Haferkamp, S. Buse, and M. Hohenfellner, "Positive surgical margins after radical prostatectomy: do they have an impact on biochemical or clinical progression?" BJU International, vol. 102, no. 10, pp. 1413-1418, 2008.

[30] G. P. Swanson, M. Riggs, and M. Hermans, "Pathologic findings at radical prostatectomy: risk factors for failure and death," Urologic Oncology, vol. 25, no. 2, pp. 110-114, 2007.

[31] S. J. Kausik, M. L. Blute, T. J. Sebo et al., "Prognostic significance of positive surgical margins in patients with extraprostatic carcinoma after radical prostatectomy," Cancer, vol. 95, no. 6, pp. 1215-1219, 2002.

[32] M. Menon, M. Bhandari, N. Gupta et al., "Biochemical recurrence following robot-assisted radical prostatectomy: analysis of 1384 patients with a median 5-year follow-up," European Urology, vol. 58, no. 6, pp. 838-846, 2010.

[33] J. A. Eastham, M. W. Kattan, E. Riedel et al., "Variations among individual surgeons in the rate of positive surgical margins in radical prostatectomy specimens," Journal of Urology, vol. 170, no. 6, pp. 2292-2295, 2003.

[34] G. Ploussard, M. A. Agamy, and O. Alenda, "Impact of positive surgical margins on prostate-specific antigen failure after radical prostatectomy in adjuvant treatment-naïve patients," BJU International, vol. 107, pp. 1748-1754, 2011.

[35] L. Budäus, H. Isbarn, C. Eichelberg et al., "Biochemical recurrence after radical prostatectomy: multiplicative interaction between surgical margin status and pathological stage," Journal of Urology, vol. 184, no. 4, pp. 1341-1346, 2010.

[36] F. Brimo, A. W. Partin, and J. I. Epstein, "Tumor grade at margins of resection in radical prostatectomy specimens is an independent predictor of prognosis," Urology, vol. 76, no. 5, pp. 1206-1209, 2010.

[37] C. Y. Hsu, M. F. Wildhagen, H. Van Poppel, and C. H. Bangma, "Prognostic factors for and outcome of locally advanced prostate cancer after radical prostatectomy," BJU International, vol. 105, no. 11, pp. 1536-1540, 2010.

[38] V. Ficarra, G. Novara, S. Secco et al., "Predictors of positive surgical margins after laparoscopic robot assisted radical prostatectomy," Journal of Urology, vol. 182, no. 6, pp. 2682$2688,2009$.

[39] K. W. Kwak, H. M. Lee, and H. Y. Choi, "Impact of capsular incision on biochemical recurrence after radical perineal prostatectomy," Prostate Cancer and Prostatic Diseases, vol. 13, no. 1, pp. 28-33, 2010.

[40] K. Hashimoto, N. Masumori, F. Takei et al., "Prognostic value of surgical margin status for biochemical recurrence following radical prostatectomy," Japanese Journal of Clinical Oncology, vol. 38, no. 1, pp. 31-35, 2008.

[41] A. Y. Chuang, M. E. Nielsen, D. J. Hernandez, P. C. Walsh, and J. I. Epstein, "The significance of positive surgical margin in areas of capsular incision in otherwise organ confined disease at radical prostatectomy," Journal of Urology, vol. 178, no. 4, pp. 1306-1310, 2007.

[42] P. I. Karakiewicz, J. A. Eastham, M. Graefen et al., "Prognostic impact of positive surgical margins in surgically treated prostate cancer: multi-institutional assessment of 5831 patients," Urology, vol. 66, no. 6, pp. 1245-1250, 2005.

[43] P. Swindle, J. A. Eastham, M. Ohori et al., "Do margins matter? The prognostic significance of positive surgical margins in radical prostatectomy specimens," Journal of Urology, vol. 174, no. 3, pp. 903-907, 2005.

[44] S. Alkhateeb, S. Alibhai, N. Fleshner et al., "Impact of positive surgical margins after radical prostatectomy differs by disease risk group," Journal of Urology, vol. 183, no. 1, pp. 145-150, 2010.

[45] J. L. Wright, B. L. Dalkin, L. D. True et al., "Positive surgical margins at radical prostatectomy predict prostate cancer specific mortality," Journal of Urology, vol. 183, no. 6, pp. 2213-2218, 2010.

[46] A. J. Stephenson, D. P. Wood, M. W. Kattan et al., "Location, extent and number of positive surgical margins do not improve accuracy of predicting prostate cancer recurrence after radical prostatectomy," Journal of Urology, vol. 182, no. 4, pp. 1357-1363, 2009.

[47] I. M. Van Oort, H. M. Bruins, L. A. L. M. Kiemeney, B. C. Knipscheer, J. A. Witjes, and C. A. Hulsbergen-Van De Kaa, "The length of positive surgical margins correlates with biochemical recurrence after radical prostatectomy," Histopathology, vol. 56, no. 4, pp. 464-471, 2010.

[48] A. M. Lake, C. He, and D. P. Wood Jr., "Focal positive surgical margins decrease disease-free survival after radical prostatectomy even in organ-confined disease," Urology, vol. 76, pp. 1212-1216, 2010.

[49] S. Shikanov, J. Song, C. Royce et al., "Length of positive surgical margin after radical prostatectomy as a predictor of biochemical recurrence," Journal of Urology, vol. 182, no. 1, pp. 139-144, 2009.

[50] M. A. Goetzl, R. Krebill, T. L. Griebling, and J. B. Thrasher, "Predictors of positive surgical margins after radical perineal prostatectomy," The Canadian Journal of Urology, vol. 16, no. 2, pp. 4553-4557, 2009.

[51] R. A. Marks, M. O. Koch, A. Lopez-Beltran, R. Montironi, B. E. Juliar, and L. Cheng, "The relationship between the extent of surgical margin positivity and prostate specific antigen recurrence in radical prostatectomy specimens," Human Pathology, vol. 38, no. 8, pp. 1207-1211, 2007.

[52] A. N. Vis, F. H. Schröder, and T. H. van der Kwast, "The actual value of the surgical margin status as a predictor of disease progression in men with early prostate cancer," European Urology, vol. 50, no. 2, pp. 258-265, 2006.

[53] R. E. Emerson, M. O. Koch, T. D. Jones, J. K. Daggy, B. E. Juliar, and L. Cheng, "The influence of extent of surgical margin positivity on prostate specific antigen recurrence," Journal of Clinical Pathology, vol. 58, no. 10, pp. 1028-1032, 2005.

[54] M. Sofer, K. L. Hamilton-Nelson, F. Civantos, and M. S. Soloway, "Positive surgical margins after radical retropubic prostatectomy: the influence of site and number on progression," Journal of Urology, vol. 167, no. 6, pp. 2453-2456, 2002.

[55] G. Fromont, X. Cathelineau, F. Rozet, D. Prapotnich, P. Validire, and G. Vallancien, "Impact of margin size on the incidence of local residual tumor after laparoscopic radical 
prostatectomy," Journal of Urology, vol. 172, no. 5, pp. 18451847, 2004.

[56] G. Godoy, B. U. Tareen, and H. Lepor, "Is the apical soft tissue margin a better predictor of biochemical recurrence than the surgical specimen?" Urologic Oncology. In press.

[57] J. A. Pettus, C. J. Weight, C. J. Thompson, R. G. Middleton, and R. A. Stephenson, "Biochemical failure in men following radical retropubic prostatectomy: impact of surgical margin status and location," Journal of Urology, vol. 172, no. 1, pp. 129-132, 2004.

[58] A. Y. Chuang and J. I. Epstein, "Positive surgical margins in areas of capsular incision in otherwise organ-confined disease at radical prostatectomy: histologic features and pitfalls," American Journal of Surgical Pathology, vol. 32, no. 8, pp. 12011206, 2008.

[59] D. Cao, A. S. Kibel, F. Gao, Y. Tao, and P. A. Humphrey, “The gleason score of tumor at the margin in radical prostatectomy is predictive of biochemical recurrence," American Journal of Surgical Pathology, vol. 34, no. 7, pp. 994-1001, 2010.

[60] M. O. Idowu, L. G. Bekeris, S. Raab, S. G. Ruby, and R. E. Nakhleh, "Adequacy of surgical pathology reporting of cancer: a college of American pathologists q-probes study of 86 institutions," Archives of Pathology and Laboratory Medicine, vol. 134, no. 7, pp. 969-974, 2010. 


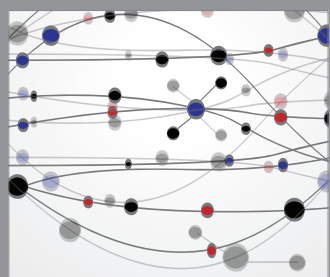

The Scientific World Journal
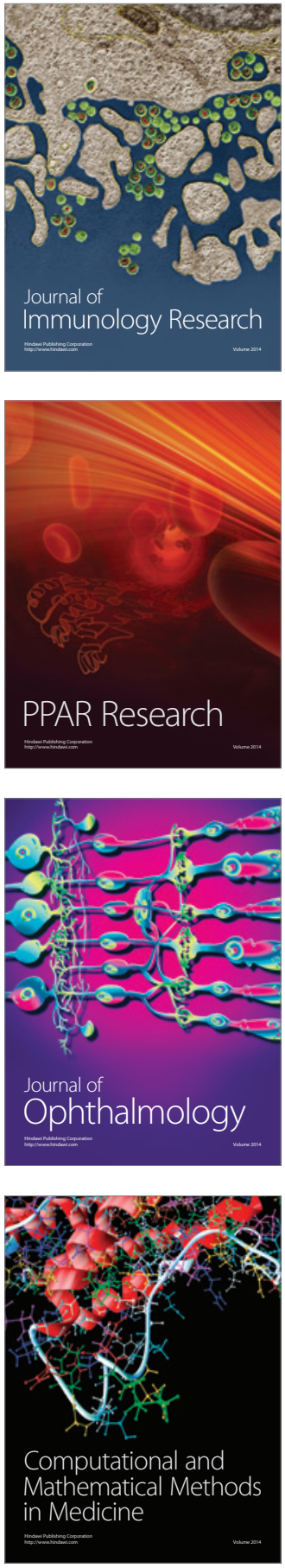

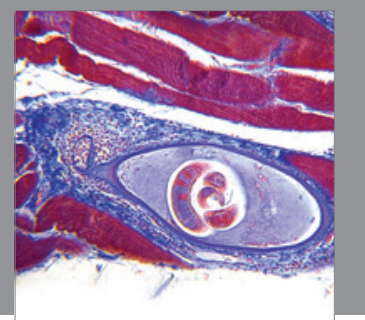

Gastroenterology

Research and Practice
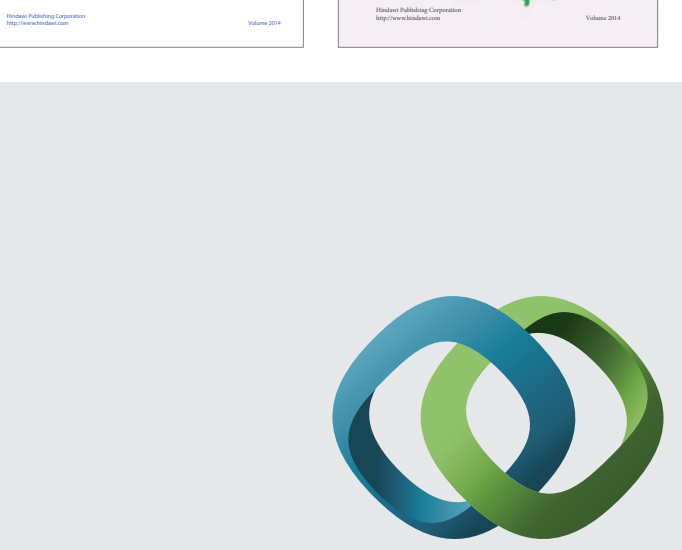

\section{Hindawi}

Submit your manuscripts at

http://www.hindawi.com
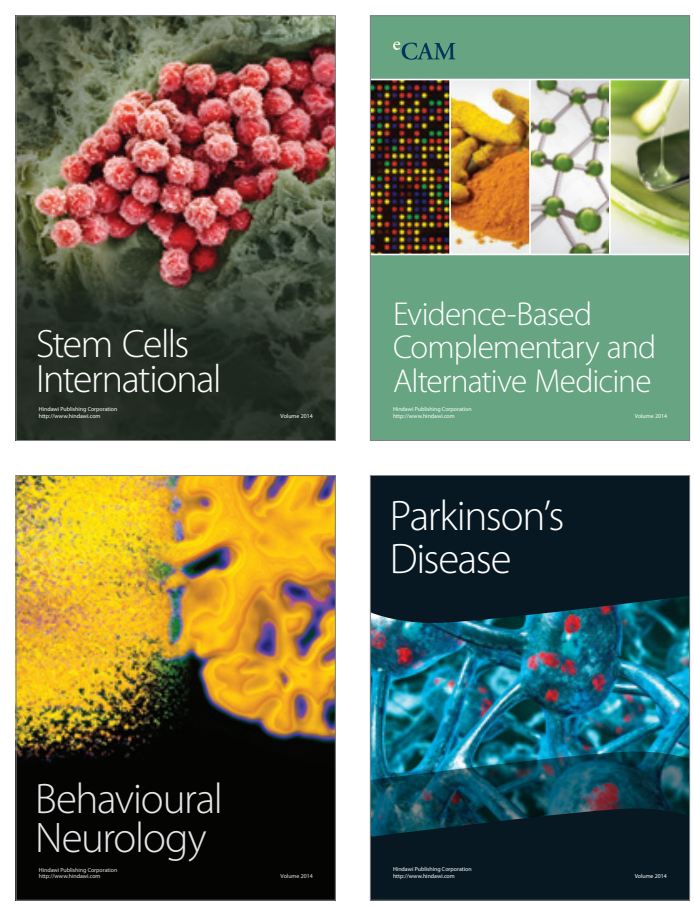

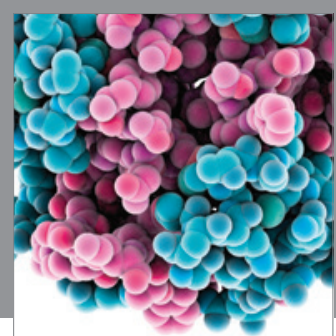

Journal of
Diabetes Research

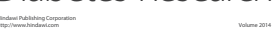

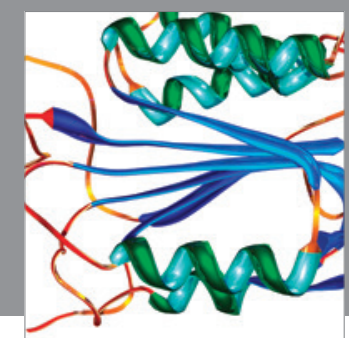

Disease Markers
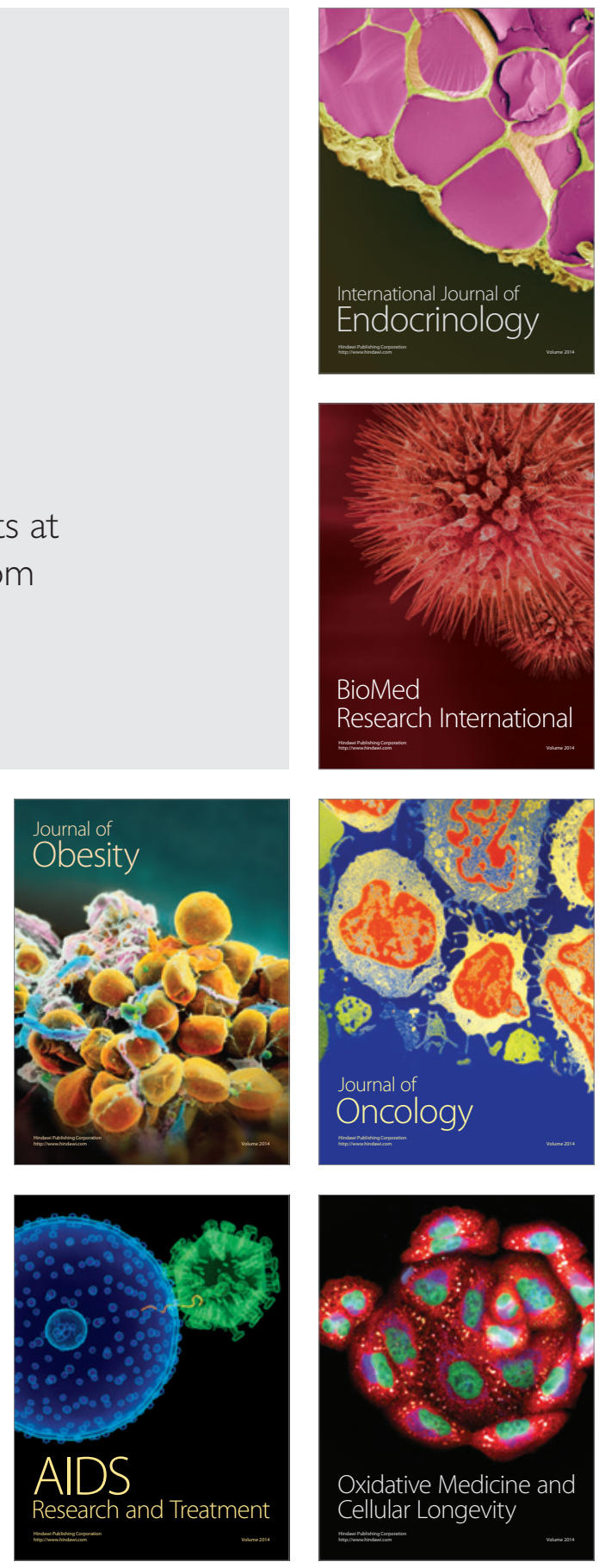